\title{
Exploratory Pollen Analysis of Hargrove Lake, Davy Crockett National Forest Houston County, Texas
}

Gerald K. Kelso

Follow this and additional works at: https://scholarworks.sfasu.edu/ita

Part of the American Material Culture Commons, Archaeological Anthropology Commons, Environmental Studies Commons, Other American Studies Commons, Other Arts and Humanities Commons, Other History of Art, Architecture, and Archaeology Commons, and the United States History Commons

Tell us how this article helped you.

This Article is brought to you for free and open access by the Center for Regional Heritage Research at SFA ScholarWorks. It has been accepted for inclusion in Index of Texas Archaeology: Open Access Gray Literature from the Lone Star State by an authorized editor of SFA ScholarWorks. For more information, please contact cdsscholarworks@sfasu.edu. 
Exploratory Pollen Analysis of Hargrove Lake, Davy Crockett National Forest Houston County, Texas

\section{Creative Commons License}

\section{(c) (1) \&}

This work is licensed under a Creative Commons Attribution-NonCommercial 4.0 International License 
Journal of Northeast Texas Archaeology No. 16 (2002)

\title{
Exploratory Pollen Analysis of Hargrove Lake, Davy Crockett National Forest Houston County, Texas
}

\author{
Gerald K. Kelso
}

\section{OBJECTIVES AND INTRODUCTION}

The objectives of this exploratory pollen analysis of selected samples from a sediment core taken at Hargrove Lake, Davy Crockett National Forest, Houston County, Texas, are to ascertain the quality of pollen preservation in the lake bottom matrix and to evaluate the potential of the pollen spectra deposited in the lake for providing information about former environmental conditions on Davy Crockett National Forest. Hargrove Lake is a natural lake in the floodplain of the Neches River in Houston County, Texas (Figures 1 and 2). The Hargrove Lake site (41HO150) lies a short distance to the west (Jurney 2000). The lake is presently is surrounded by a $10 \mathrm{~m}$ wide stand of buttonbush (Cephalanthus). These plants are three $\mathrm{m}$ tall and have two to ten $\mathrm{cm}$ diameter trunks. A woodland dominated by water oaks (Quercus nigra) and sweetgum (Liquidambar styraciflua) lies beyond the buttonbush. These trees are 30 to $40 \mathrm{~m}$ tall, and the woodland canopy is 90 to 98 percent closed. The lake is normally about $50 \mathrm{~m}$ wide by $200 \mathrm{~m}$ long, giving it a normal surface area of approximately 2.5 hectares. The mean depth of the lake at high water is about $90 \mathrm{~cm}$. Bedrock marl underlies the area, and the lake retains water during even the most severe droughts. It should provide a continuous pollen deposition record.

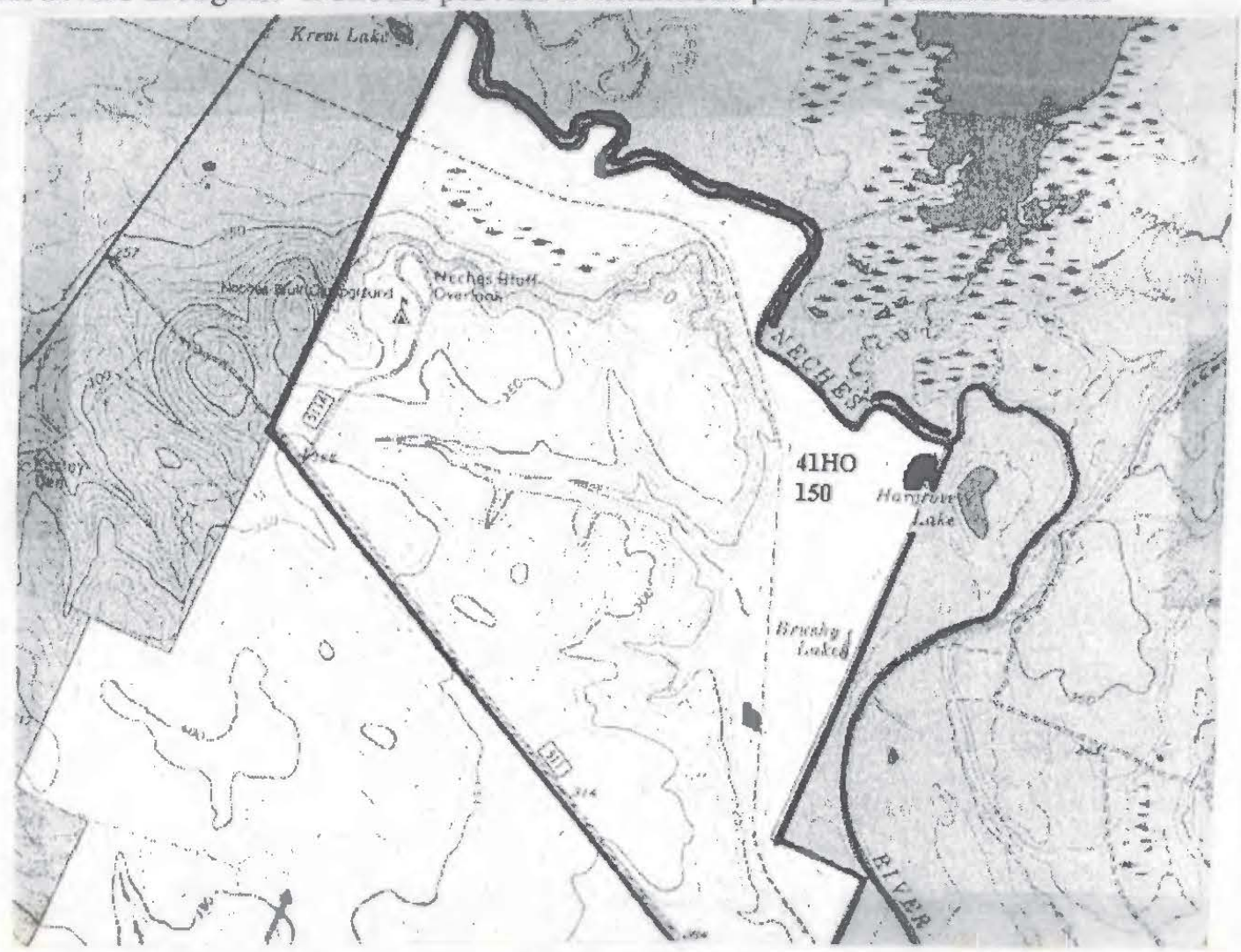

Figure 1. The location of Hargrove Lake adjacent to the Hargrove Lake site (41HO150). 


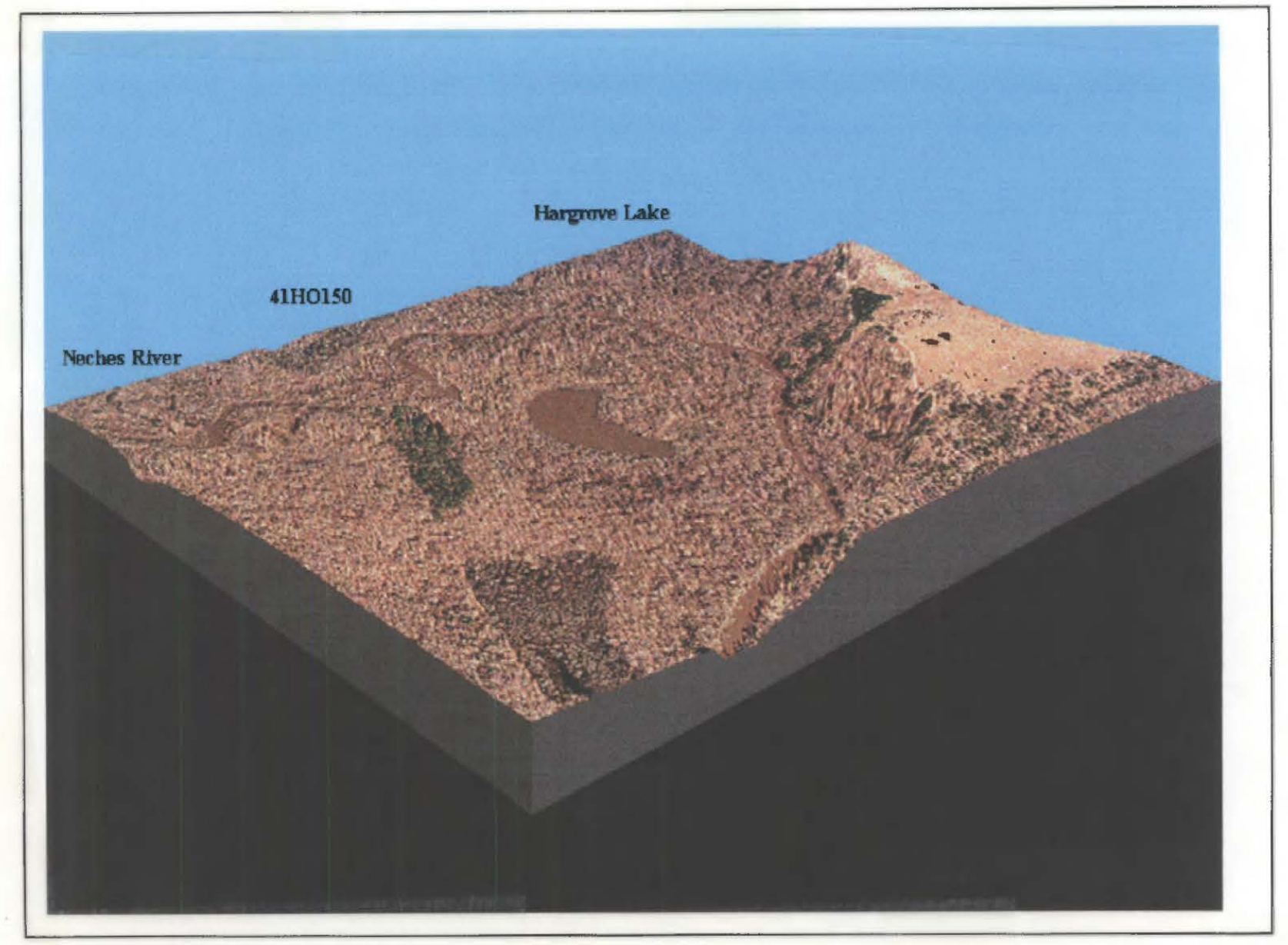

Figure 2. Three-dimensional infrared photograph of the Hargrove Lake area.

The size of the source area for the pollen in Hargrove Lake has yet to be determined. Tauber (1965:32) estimated from his theoretical pollen dispersal data for European forests that the effective source area for pollen deposited in a small lake or bog ( 100 to $200 \mathrm{~m}$ in diameter) should extend 300 to $1,000 \mathrm{~m}$ out from the basin. Eighty percent of the pollen grains in such small lakes come from the trunk space, but deposition can be markedly altered by filtration effects in vegetation of different densities (Tauber 1965:32). Such filtration could affect the size of the pollen source area at Hargrove Lake. The dense buttonbush surrounding the lake may capture much of the pollen transported in the trunk space of the woodland. The pollen transported across the top of the woodland canopy, normally only 10 percent of a small lake spectrum (Tauber 1965:32 and Figure 7), may contribute a larger proportion of the spectrum than predicted by Tauber's $(1965: 32)$ model. This could extend the effective pollen source area out from the lake a considerable distance.

It may be possible to evaluate the size of the Hargrove Lake pollen source area by comparing the concentrations and species composition of pollen caught in a series of traps. These should be placed above the woodland canopy at several intervals from the shoreline on the side of the lake from which the prevailing winds blow, above the buttonbush, within the buttonbush trunk space at upwind side of the lake, in the woodland trunk space at upwind side of the buttonbush, in the wind shadow at the edge of the lake below the buttonbush, at the center of the lake, and at the downwind edge of the lake. 


\section{METHODS}

\section{Sampling}

Hargrove Iake was cored at its deepest point, where bottom sediments should be thickest, by then Davy Crockett National Forest Archaeologist David Jurney. 'The core was taken by driving a sharpened segment of 2 inch-inside diameter PVC pipe into the lake bottom scdiments with a sledge hammer until movement was stopped by resistant material. The depth of the drive was marked on the outside of the core pipe, and it was manually withdrawn. The core pipe was then sealed at both ends with plastic to prevent contamination.

The core was shipped to the Tombigbec Ranger District, Ackerman, Mississippi, for sampling and analysis. The core pipe was split in the laboratory with a table saw set to cut only the thickness of the PVC. Once cut, half of the split core pipe was removed and the other half used as a sampling tray. The recovered core was measured, and its stratigraphy was noted (Figure 3 ). Sediment colors were recorded using the Munsell system, and matrix textures were estimated from the feel of the sediment when rubbed between thumb and finger. The core was cut into $2 \mathrm{~cm}$ contiguous samplcs (no space between them), and the outer 0.5 inch around the circumference of cach sample was removed to preclude contamination from the core pipe wall.

\section{Laboratory Methods}

Four samples spaced through the sediment profile-PS $26(4 / 6 \mathrm{~cm}$ below the surface), PS 19 (18/20 cm bs), PS $10(36 / 38 \mathrm{~cm} \mathrm{bs})$, and PS $2(52-54 \mathrm{~cm} \mathrm{bs})$-were selected for cxploratory analysis. Pollen extraction generally followed Mehringer's (1967) mechanical/chemical procedure. His first two $\mathrm{HCL}$ washes and $\mathrm{HNO}^{3}$ step were eliminated, and the strength of the final $\mathrm{NaOH}$ wash was reduced to 0.05 percent. The acetolysis process was not employed. Residues were mounted in glycerol for viewing, and all samplcs were tabulated within five days of extraction to reduce the pollen grain size distortion that sometimes occurs with this mounting medium (Anderson 1960). Standard Southwestern 200 pollen grain tabulations (Martin 1963:31) were employed. The pollen was identified at $430 \mathrm{X}$, and problematical pollen grains were examined under oil immersion at $970 \mathrm{X}$.

Approximately 28,000 Lycopodium pollen grains were added to cach sample at the start of extraction so that Benninghofrs (1962) exotic pollen addition method could be employed in computing pollen concentrations per gram of sample. Pollen concentration figures were not calculated for individual taxa. These would not be meaningful in the absence of chronological control over sedimentation rates and might bc mistaken for pollen influx data. All pollen grains that were too degraded to be identificd were tabulated to provide control over corrosion factors. Unidentifiable pollen grains were not incorporated in any sum from which the frequencies of other types were computed; but the data for this pollen group, as a percentage of total identifiable and unidentifiable pollen, are presented for each site sample in Figure 4. The terms "corroded" and "degraded" are used interchangeably and refer to any kind of pollen deterioration other than tearing. They are not intended as references to the specific classes of deterioration defined under these terms by Cushing (1964) and Havinga (1984). 


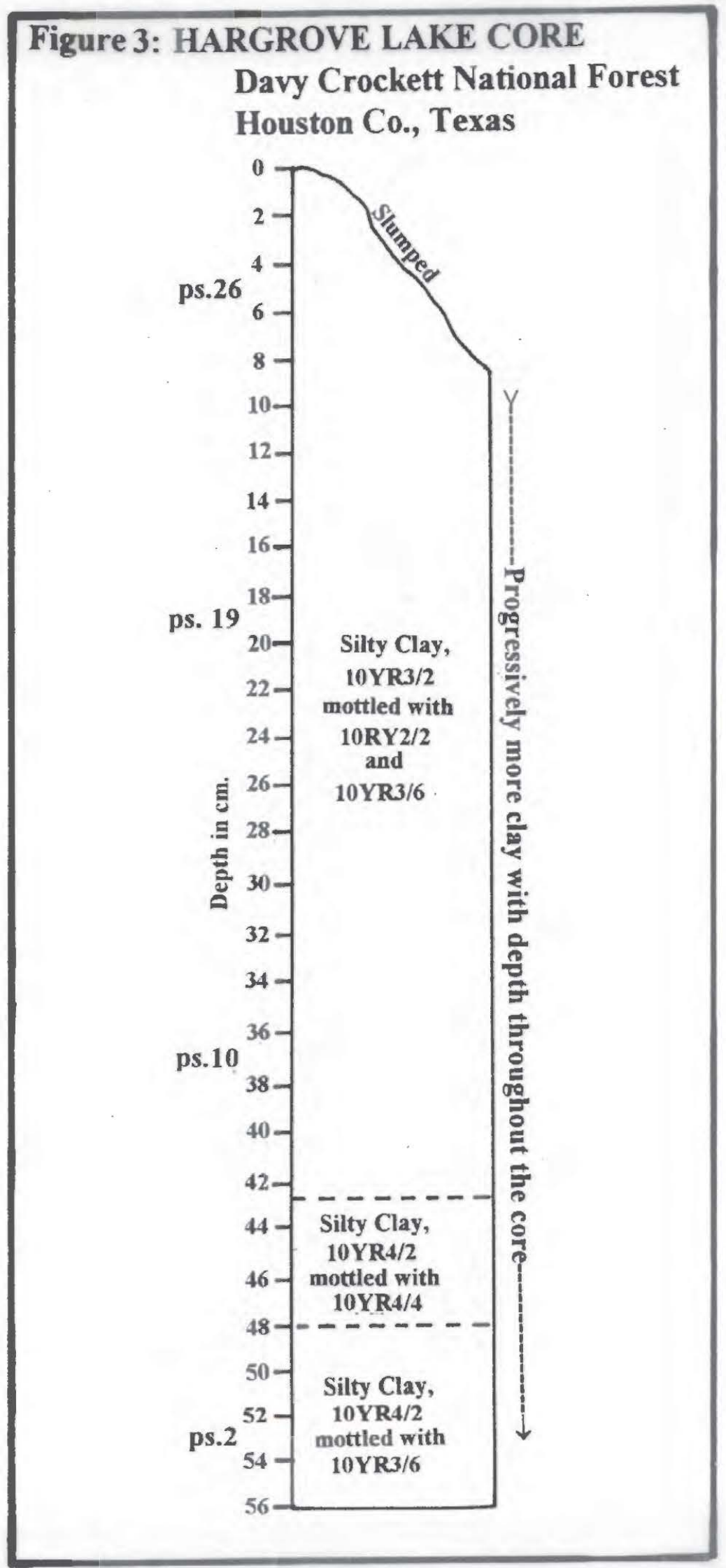

Figure 3. Hargrove Lake Core, Davy Crockett National Forest, Houston County, Texas. 
Figure 4: HARGROVE LAKE POLLEN PERCENTAGES

Davy Crockett National Forest

Houston Co., Texas

$=\%$ Based on Total Pollen Sum

- = Single Pollen Grains
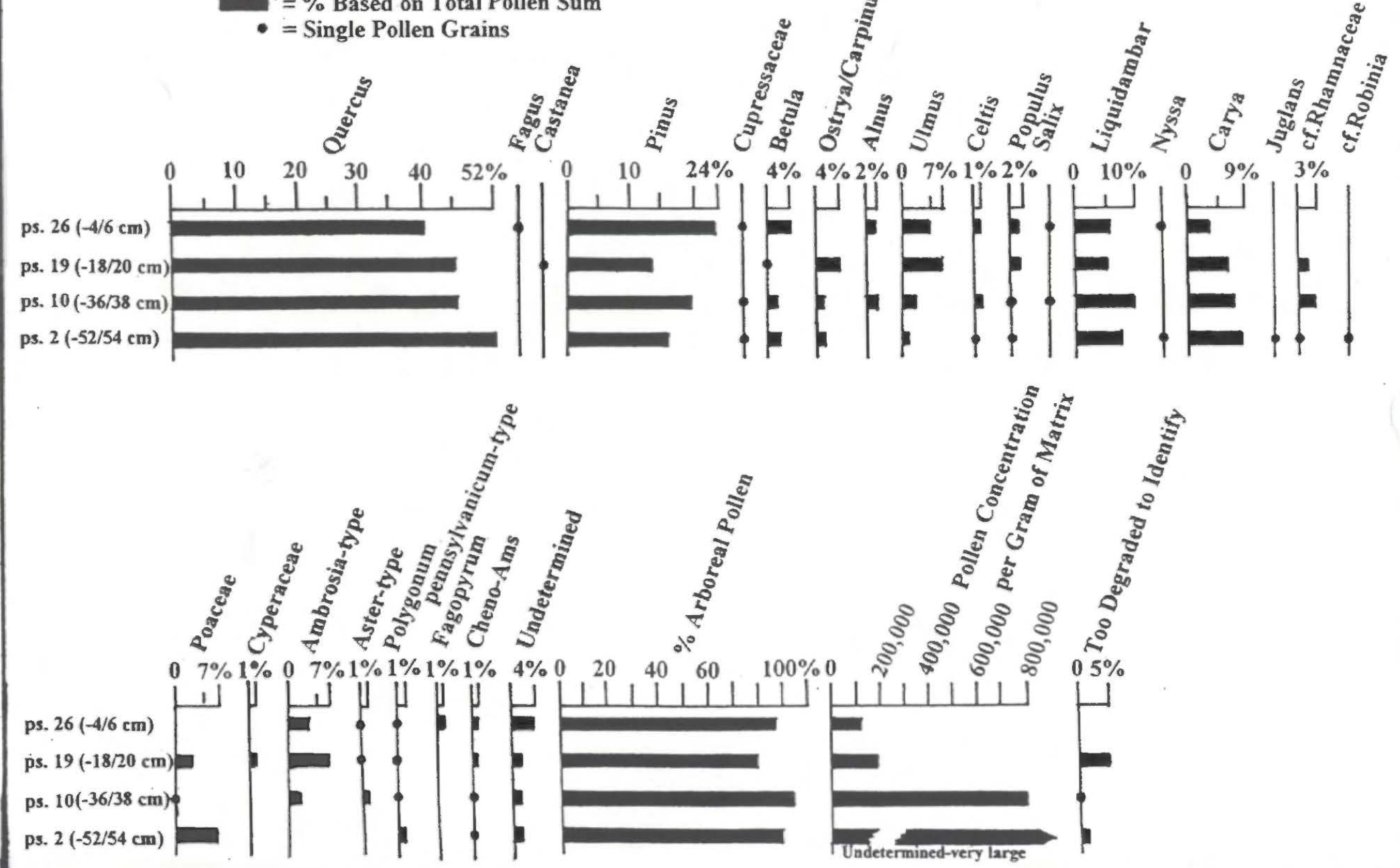
The pollen grains of the goosefoot family (Chenopodiaceae) and the amaranths (Amaranthus) cannot be distinguished except by labor intensive statistical means and are conventionally combined under the term "Cheno-Ams" (Martin 1963; McAndrews and Swanson 1967). The pollen from the aster family (Asteraceac) observed in the Hargrove Lake samples is divided into a wind-transported group (Ambrosia-type) and an insecttransported group (Aster-type) on the basis of the longer spines on the exine surface of insect-pollinated members of this family (Martin 1961:71). Common English names for plants are used in the text. They are followed by Latin names the first time that they are used, and I atin terms followed by common English names are used on the pollen diagram. Latin and common English names are listed in Table 1.

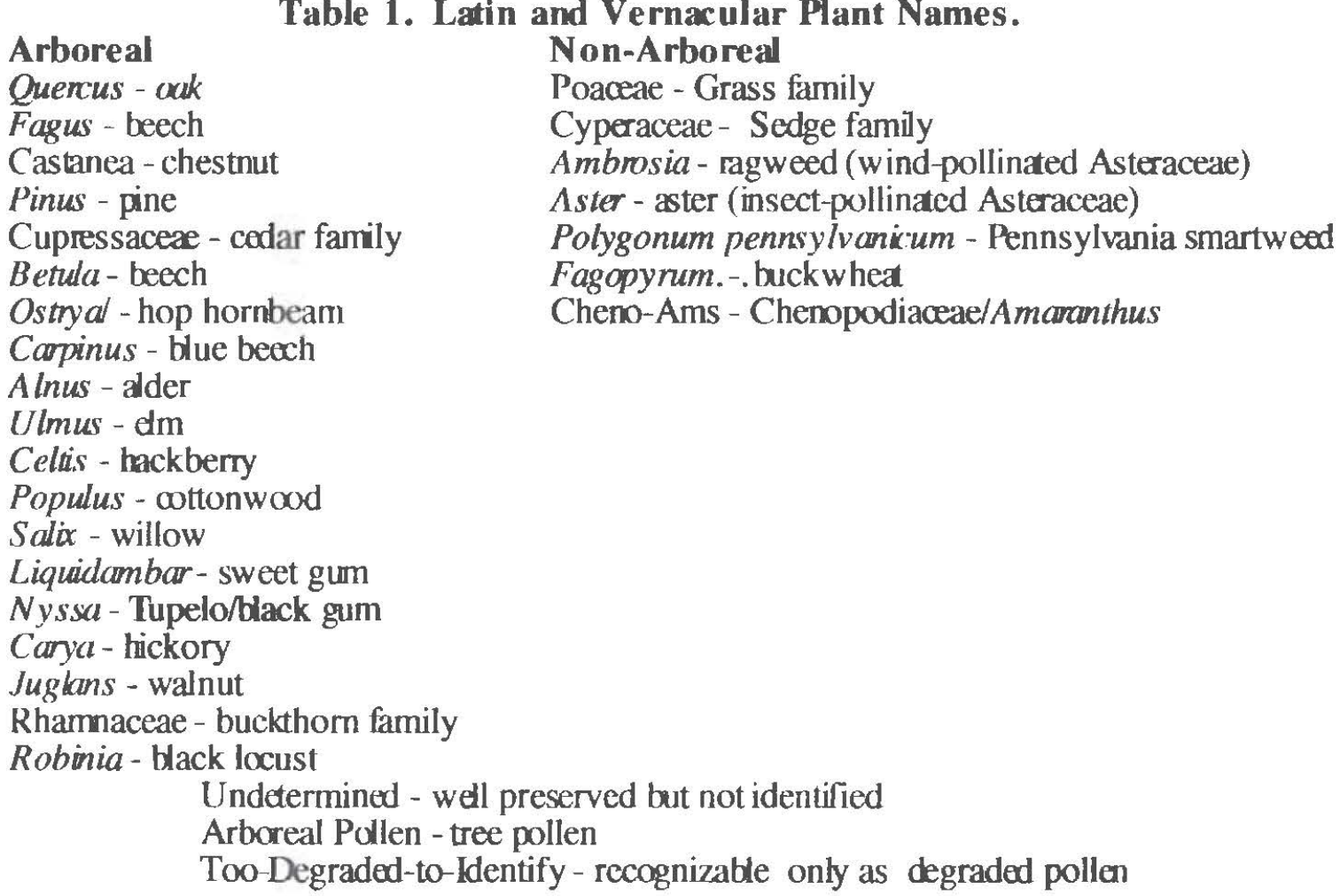

RESULTS

\section{Stratigraphy}

The upper $25 \mathrm{~cm}$ of the Hargrove Lake bottom sediment profile consisted of brown, watery silt (see Figure 3). This was lost during coring. The remainder of the core profile appears to be silty clay with a progressively larger proportion of clay with increasing depth. A $75 \mathrm{~cm}$ drive into this more solid portion of the sediment yielded a 56 cm thick core, indicating 25.4 percent matrix compression during the coring process. Some slumping occurred in the wetter upper 6-8 $\mathrm{cm}$ of the core during horizontal transport and storage before extraction (see Figure 3 ). The core as originally recovered may have been a few cm shorter than when sampled. 


\section{The Vegetation Record}

All four Hargrove Lake exploratory pollen samples are dominated by tree (arboreal) pollen (85-94.5 percent). Oak (Quercus) pollen is the most prominent type, and pine (Pinus) is the second most important pollen taxa. Herb (non-arboreal) pollen is not well represented in the serics. Only grass farnily (Poaceae) and ragweed-type (Ambrosia-type) pollen exceed one percent in any sample. There are some differences between the older and younger pollen spectra that may prove to register vegctation trends in an expanded sample series. The oak, hickory (Carya), sweetgum, and grass family pollen percentages are, for instance, gencrally higher in the tabulations from the deeper samples, while pine, elm (Ulmus), cottonwood (Populus), ragweed-type, and the Cheno-Am-type are somewhat better represented toward the top of the profilc.

Several interpretations of thesc data are possible. Environmental conditions, natural or cultural, may have changed from those favoring oak, sweetgum, and hickory to those favoring pine, elm, and cottonwood. Statistical constraint within a fixed numerical sum may also be involved here. It is possible that the parent populations of oak, sweetgum, and hickory declined, and the pollen percentages of pine, clm, and cottonwood simply expanded statistically to fill out 100 percent of the 200 grain tabulations without any increase in the populations of the parent trees. Alternativcly, the pine, elm, and cottonwood populations may have actually increased and statistically forced down the percentages of pollen contributed by stable populations of oaks, sweetgum, and hickories. Which trec taxa really increased or decreased in numbers and which pollen types statistically responded in the percentages should be easier to evaluate with an augmented sample serics. The best way, however, to resolve this question will be to calculate pollen influx for the expanded profilc. This will require generation of sedimentation rates.

The shift from grass family to ragweed-type and Cheno-Ams among the nonarborcal pollen spectra can be morc confidently addressed. Soil disturbance destroys the perenniating organs of grasses (Behre 1981:226). Ragweeds, on the other hand, are better adapted to withstand the water and temperature stress of barc, disturbed ground than most other herbs. They arc, consequently, the premier agricultural weed of eastern North America (Bazzaz 1974), and increases in ragweed-type pollen percentages in bog and lake deposits are the accepted horizon marker for the advent of Euro-American style agriculture in paleoenvironmental pollen sequences (Davis 1965:395) The apparent replacement of grass by ragwceds in the Hargrove Lakc pollen source area suggests an increase in soil disturbancc. An expanded sample series may also demonstrate that the addition of astertype (Aster-type) to the spectrum in PS 10 and the slight decline in Pennsylvania smartwecd-type (Polygonum pennsylvanicum-type) percentages in and above the same sample are also products of change in the soil stability regimen.

The Cheno-Am counts support a soil disturbance interpretation of the grass and ragwced-type percentages. The Cheno-Ams are the primary soil disturbance indicator in prchistoric sites in the southwcstern United States: increasing in frequency as sites werc established, decreasing again at abandonment, and increasing again at reoccupation (Kclso 1980:350 and Figure 161). The plants producing this pollen type favor fertile soils (Behre 1981:236; Muenscher 1980:180-196), and they prolifcrate on the flood-renewed soils of Midwestem floodplains as well as in the nutrient-rich soils around stockyards and cattle tanks. The modest increase in Cheno-Am percentages suggests utilization of the lake as a water source by cattle during the historical-era.

Disturbance aerates the soil and provides agents of pollen degradation, primarily free oxygen (Havinga 1969) and aerobic fungi (Goldstein 1960), with access to pollen already in sediments. Quantities of pollen too-degraded-identify, consequently, register 
relative soil disturbance (Kelso 1993:71 and Figure 1). The peak of pollen too-degraded-to identify in Hargrove Lakc sample PS 19 coincides with the largest tabulation of ragweedtype pollen in the sample series and supports the inference that the grass to ragweed shift resulted from increased soil disturbance. Such disturbance is not necessarily of agricultural origin. Natural erosion (Solomon et al. 1983) during a dry interval or simply exposure of the matrix to the atmosphere could also both encourage ragweed and damage pollen.

The only scdge (Cyperaceae) pollen to appcar in the Hargrove Lake exploratory samples also occurs in sample PS 19 (see Figure 4). Sedge pollen is very heavy and was undetectablc beyond $1 \mathrm{~m}$ from the parent plants in an experimental study (Handle 1976). The Hargrove Lake sedge pollen must have come from the immediate vicinity and suggest a period of low water with bottom exposed around the periphery of the lake. Such bottom cxposure would also account for the increase in the quantity of degraded pollen in the sample containing the sedge pollen. Alternatively, churning of the soil at the water's edge by cattle could have caused the pollen degradation, and crcatcd the habitat for both sedges and ragweed.

It does not automatically follow that these changes in the herb pollen spectra and pollen preservation measure occurred during the Euro-amcrican era. Increases in ragwecd pollen in New England have been dated to ca. 7,300 ycars ago (Sneddon and Kaplan 1987:7; Winkler 1985:8; Davis 1969:419; Kelso 1991) and are considered to record a continental scale mid-Holocene dry period in polten spectra recovercd in the Southwestem United States (Mehringer 1966:97). At Pocksha Marsh, Middleborough, Massachusetts, coincident increases in ragweed and quantities of degraded pollen during the Hypsithermal reflected a combination of climatic change and shect crosion off of the hilside above the marsh (Kelso 1991). Ragweed-type pollen appears deep in the Hargrove Lake core but not at the bottom, whilc buckwheat (Fagopyrum), the lone Hargrove Lake pollen type from a plant of undoubted Eurasian origin, was noted only in the most shallow of the four exploratory pollen samples. Both historical-era soil disturbancc and a prehistoric dry episodc could appear in an expanded sample series.

No buttonbush pollen was noted in any of the four exphratory pollen samples. Buttonbush pollen is distinctive (Kapp 1969.145), is produced in abundant quantities (Radforce et al. 1968:979), and does not appear to be coated with the sticky oils and resins characteristic of insoct-pollinated taxa (Fagri and van der Pijl 1971). Buttonbush pollen should have been found in at least the most shallow sample of the series. The absence of the type suggests either that the buttonbush fringe around the lake is a very recent devdopment or that the plants on the periphery of the lake have been mis-identified. It will be necessary to develop a vegetation map of the area around the lakc. This will facilitate interpretation of the lake polken spectra and the data from the pollen source area study.

The absence of buttonbush pollen emphasizes the poor representation of all herbaccous pollen in the spectra. The non arboreal sum does not cxcoed 15 percent in any of the Hargrove Lake samples analyzed to date and pollen sums larger than the standard Southwestem 200 grain tabulations should be employed to improve the representation of herbs and minor tree pollen types (Duffield and King 1980). This will bolster the analyst's confidence in patterns discrnible among the herb polken spedra.

\section{Pollen Concentrations}

All four Hargrove Lake exploratory samples contained adcquate pollen to permit tabulation of 200 grain counts in a few hours each. Pollen concentrations in the deeper two samples (see Figure 4, lower right) are much larger than those previously recovered by the analyst from lake and marsh sediments in the Northeastern United States. In the deepest 
sample the quantity of native pollen was so large that that none of the Lycopodium pollen added at the beginning of extraction was noted during the tabulation on the 200 native pollen grains. The tracer pollen type was observed in a subsequent scan of the slide. Larger quantities of exotic pollen will have to be added to future extractions to insure that it is recorded during tabulation of the native sum. Adding larger quantities of exotic pollen will also reduce the clement of chance in encountering the exotic pollen during tabulations of all samples and, consequently, statistically improve the accuracy of the calculated pollen concentrations and influx data.

The pollen concentrations decrease from the deepest to the most shallow of the Hargrove Lake exploratory samples. No age determinations from which sedimentation rates can be generated for the lake are yet available (see Endnote by David H. Jurney and Timothy K. Perttula), and the pollen concentrations cannot be converted into pollen influx rates at the present time. Lacking such chronometric data, the decline in pollen conccntrations can be interpreted in three ways:

1) It may reflect a decrease in the density of the vegetation contributing to the pollen spectrum;

2) It may indicate a changing matrix cnvironment, resulting in progressively greater pollen destruction later in the deposition sequence; and

3) It may register an acclerating sedimentation rate through time.

The first potential explanation appears unlikely because the declines in the oak, sweetgum, and hickory percentages are much less than the amount suggested by the proportions of the decrease in pollen concentrations. In situ pollen destruction also appears improbable because the quantities of pollen too-degraded-to-identify ncver exceed five percent in any of the four samples, and no degraded pollen was noted where pollen concentrations are lowest at the top of the profile. This leaves an increase in the sedimentation rate as the most probable cause of the progressive decline in pollen concentrations from the bottom to the top of the Hargrove Lake sample scries.

Large increases in the sedimentation rate comparable to that suggested by the Hargrove Lake pollen concentrations appear to be historical-era phenomena. At Nauset Marsh, Capc Cod, Massachusetts, the post-settlement rate was 370 percent of the prehistoric rate (Kelso 1994). 'The rate at Pearson's Pond on the San Francisco Peninsula in California, calculated from dates and historical markers presented by Adam (I975:730 and Table 1), increased by 760 percent with the advent of logging and grazing. The historical-era rate in an estuary on Santa Rosa Island, California, was 1900 percent of the prehistoric rate on the average and rose to 3300 percent of the prehistoric rate between 1874 and 1920 (Cole and Liu 1994:334). It appears probable that the progressive decline in pollen concentrations per gram of matrix in the Hargrove Lake core is also the product of an increase in sedimentation rate resulting from an intensification of human activities in the vicinity of the lake during the historical era. The sedimentation rate will have to be investigated. Radiocarbon dating should be sufficiently precise for the deeper, prehistoric, portion of the core. Sedimentation rates for the Euro-American era can be generated with $\mathrm{Pb}^{210}$ dates and pollen horizon markers for dated cvents that affected the vegetation. Documentary and oral history research will be requircd to establish pollen horizon markers.

In a series of only four widely spaced samples it is not possible to determine the point in the depositional history of the lake at which the scdimentation rate began to 
increase. If, however, the advent of ragweed-type pollen in the herb pollen spectrum is a horizon marker for the beginning of the Euro-American-cra, the sedimentation rate probably began to accelerate between PS 10 and PS 2. This would mean that only onc third, or less, of the profile dates to the prehistoric period. If the range of variation of the pre-European settlement vegetation within the Hargrove I ake pollen source area is to be defined, contiguous pollen samples will have to be analyzed from the deeper portion of the core. The resolution of events in the historical-cra vegetation history for the vicinity will also be improved by employing contiguous samples throughout the core.

\section{DISCUSSION AND RECOMMENDATIONS}

Abundant pollen was recovered from all four Hargrove Lake exploratory samples, and several probable trends are evident among both the tree and herb pollen spectra of the Hargrove Lake exploratory samples. In an expanded sample series, these will probably register systematic vegetation changes interpretable as the result of changes in environmental and cultural history. Oak, sweetgum, and hickory percentages decline toward the top of the sample scries in the tree spectrum, whilc the pine, elm, and cottonwoods increase. It appears probable that the decreases in the first three types reflect actual events, while the increases in the second three pollen types are statistical responses within a fixed numerical sum. It is possible, however, that there were real increases in the numbers of pine, elm, and cottonwood trees in the pollen source area. This question should be resolved by generating pollen influx data for the core. This will require an accuratc history of sedimentation rate changes based on radiocarbon dates, $\mathrm{Pb}^{210}$ dates, and pollen horizon markers for dated events spaced through the core.

The grass family is better represented toward the bottom of the hcrb pollen spectrum, ragweed-type appears in the upper threc pollen samples, and goosefoot/amaranth percentages are slightly larger in the most shallow two samples. These changes suggest an increase in soil disturbance in the upper thrce quarters of the core with some enrichment of the soil in the upper half of the sequence. Pcaks of ragweed-type and degraded pollen percentages in sample PS 19 are accompanicd by the only sedge pollen noted in the sample series. These three phenomena suggest a low water episode with somc bottom exposed around the edgc of the lake or an increase in soil disturbance at the water's cdge.

A stcady decline in pollen concentrations per gram of matrix appears to register a rather large increase in sedimentation rate. Such increases at othcr sites were caused by the soil disturbance that is charactcristic of Euro-American-era land-use practices. The herb pollen spectra suggest that the onset of such soil disturbance in the Hargrove Lake pollen source area occurred sometime between the deposition of the PS 2 and the PS 10 matrix. If this interpretation is corrcct, it is probable that less than one-third of the profile was deposited during the prehistoric period. In order to rccover a reasonably complete range of variation for the late prehistoric period, it will be ncccssary to analyze contiguous samples from this portion of the core. Contiguous sampling for the entire core will improve the historical-era vegetation record as well.

Herb pollen will be very important in the interpretation of the Hargrove Lake record, but the herb spectrum constitutes no morc than 15 percent of any sum tabulated to datc. In order to define patterns among the herb pollen types that the analyst can interpret with confidence, it will be necessary to tabulate largc sums -400 to 1,000 grains-per sample or to do a second of several hundred grains from which tree pollen is excluded. This should be economically feasible, given the relatively high pollen concentrations in all samples. Rc-sampling the lake with a stationary piston corer or a vibration corer might improve the accuracy of sedimentation rate and pollen influx data by reducing matrix

compression. Analysis of the lake pollen spectra should also benefit from a study of the 
pollen source area. This could be accomplished with a series of pollen traps placed across the lake and surrounding woodland, according to the prevailing winds in the arca, and should be accompanied by an inventory of the present vegetation in the area.

\section{END NO'TE}

\section{David H. Jurney and Timothy K. Perttula}

Subsequent to the completion of the report by Gerald Kelso published herein, three radiocarbon dates have bcen obtained from the Hargrove Lake pollen core. The dates were on pond sediments collccted from PS 20 (16-18 cm bs), PS $11(34-36 \mathrm{~cm}$ bs), and PS 3 $(50-52 \mathrm{~cm}$ bs). The PS 20 assay is modern $(106.0 \pm 0.5$, Beta-156370, -27.0 o/ $13 \mathrm{C} / 12 \mathrm{C}$ ratio), indicating that at least the upper $20 \mathrm{~cm}$ of the pond deposits have been contaminated since the 1950 s.

The other two samples have the following two sigma calibrated age ranges (see Stuiver et al. 1998; Talma et al. 1993):

PS 11, cal AD 1310-1430 (Bcta-156513, -26.9 o/oo)

PS 3, cal BC. 30 to AD 70 (Bcta-156369, -27.2 o/oo).

Since the PS 3 date is from near the bottom of the pollen core, it is apparent that the pollen data from Hargrove Lake are relevant concerning changes in pollen and local vegetation from about the last 2000 years. Sediments accumulated very slowly in the lake, based on the two calibrated radiocarbon dates, at about $1.16 \mathrm{~cm}$ per 100 years. An additional radiocarbon sample date between PS 11 and PS 3 would better clarify the sedimentation rate in thesc Late Holocene sediments.

Assuming that the top of the sediment corc represents deposition in modern times (ca. 1950), the upper $34 \mathrm{~cm}$ of the Hargrove Lake sediment core accumulated about 540 percent faster than in prehistoric times: $6.3 \mathrm{~cm}$ per 100 years. An additional radiocarbon sample date between PS 20 and PS 11 would better clarify when sedimentation rates began to increase, and also better establish which pollen samples datc prior to Euro-American settlement in this part of the Neches River valley.

\section{REFERENCES CITED}

Adam, David P.

1975 A Late Holocene Pollen Record from Pearson's Pond, Weeks Creek Landslide, San Francisco, Peninsula, California. Joumal of Research, U. S. Geobgical Survey 3(6):721-73I.

Bazraz, F. A.

1974 Ecophysiology of Ambrosia Artemisiifolia: A Successional Dominant. Ecokgy 55:112-119.

Behre, Kart-Ernst

1981 The Interpretation of Anthropogenic indicators in Polkn Diagrams. Pollen et Spores 23(2):225-24.5. 
Benninghoff, Willard S.

1962 Calculation of Polken and Spores Density in Sediments by Addition of Exotic Pollen in Known Amounts. Pollen et Spores 6(2):332-333.

Cole, Kenneth L. and Genurwu Liu

1994 Holocene Paleoecology of an Estuary on Santa Rosa 1stand, California. Quaternary Rescurch 41:326-335.

Cushing, E. J.

1964 Redeposited Pollen in Late Wisconsin Pollen Spectra from East-Central Minnesota. American Joumal of Science 262:1075-1088.

Davis, Margaret B.

1965 Phytogeography and Palynology of the Northeastem United States. In The Quaternary of the United States, edited by H. E. Wright Jr. and D. G. Frey, pp. 377401. Princeton University Press, Princcton, New Jersey.

1969 Climatic Change in Southern Connecticut Recorded by Pollen Deposition at Rogers Lake Ecology 50:409-422

Duffield, Rose and James E. King

1980 Sample Size and Palynology: A Midwestern Test Transactions of the Illinois State Academy of Science 72(2):1-7. Springfield, Illinois.

Faegri, K. and L. Van der Pijl

1971 Principles of Poltination Ecology. Pergamon Press, New York

Goldstein, S.

1960 Degradation of Pollen by Phycomycetes. Ecology 41:543-545.

Handel, S. N.

1976 Restricted Pollen Flow of Two Woodland Herbs Detormined by Neutron Activation Analysis. Nature 260:422-423.

Havinga, A. J.

1963 A Palynological Investigation of Soil Profiles Devdoped in Sand Cover. Mededelingen von de Landbouw-hogschool te Wageningen, Nederland 63:1-92.

1984 A 20 Year Investigation into Differential Cormosion Suscetibility of Polken and Spores in Various Soil Types. Pollen et Spores 26 (34):541-558.

Jurney, David H.

2000 Archueological Investigations at the Hargrove Lake Site (41HOI50), Davy Crockett National Forest, Houston County, Texas: 1997 Season. U.S. Department of Agriculture-Forest Service, Lufkin, Texas.

Kapp, Ronald O.

1969 How to Know Pollen and Spores. William C. Brown Co. Dubuque, Iowa

Kelso, Gerald K.

1980 Palynology and Human Paleoecology in Dead Valley. In Prehistory in Dead Valky, East Central Arizona: The TG\&ESpringerville Project, edited by D. E. Doyle and S. S. Debrowski, pp. 349-370. Arizona State Musaum Archaeological Scries No. 144. Arizona State Museum, Tucson, Arimona 
1991 Pollen Analysis at Pocksha Marsh, Middleborough, Massachusetts. Manuscript on file at Middleborough Conservation Commission, Middleborough, Massachusetts.

1992 Pollen Analysis of Cores 9 and 6a, Nauset Marsh, Cape Cod, Massachusetts. Report on file at Cultural Ecology Laboratories, Ackerman, Mississippi.

1993 Pollen-Record Formation Processes, Interdisciplinary Archaeology, and I and Use by Mill Workers and Managers: The Boott Mills Corporation, Lowdl, Massachusetts, 1836-1942. Historical Archaeology. 27(1):71-93.

Martin, Paul $\mathrm{S}$.

1963 The Last 10,000 Years. University of Arizona Press, Tucson, Arizona.

McAndrews, John H. and A R. Swanson

1967 The Pore Number of Pcriporate Pollen with Special Refcrence to Chenopodium. Review of Palaeobotany and Palynology 3:105-117.

Mehringer, Pettr J. Jr.

1966 Pollen Analysis and the Alluvial Chronology. Kiva 10:96-101

1967 Pollen Analysis of the Tule Springs Area, Nevada. In Pleistocene Studies in Southem Nevada, edited by H. M. Wormington and D. Ellis, pp. I20-200. Nevada State Museum Anthropological Papers 13. Nevada State Museum, Carson City.

Munascher, Walter C.

1980 Weeds. Corncll University Press, Ithaca, Ncw York.

Radforce, Albert E., Harry E Ahles, and C. Ritchie Bell

1968 Manual of the Vascular Plants of the Carolinas. University of North Carolina Press, Chapel Hill.

Sneddon, Leslie and I awrence Kaplan

1987 Pollen Analysis for Cedar Swamp Pond. Archaeological Quarterly 9(2):1-16. Westborough, Massachusetts.

Solomon, A. M., T. J. Blasing and J. A. Solomon

1983 Interpretation of Floodplain Pollen in Alluvial Sediments from an Arid Region. Quaternary Research 18:52-71.

Stuiver, M. et al.

1998 INTCAL98 Radiocarbon Agc Calibration. Radiocarbon 40(3): 1041-1083.

Talma, A. S. and J. C. Voge

1993 A Simplifed Approach to Calibrating C14 Dates. Radiocarbon 35(2):317-322.

Tauber, Hennik.

1965 Differcntial Polkn Dispersion and Filtration. In Quaternary Paleoecology, edited by E. J. Cushing and H. E. Wright Jr., pp. 131-141. Yale University Press, New Haven.

Winkler, Majorie G.

1985 A 12,000-Year History of Vegetation and Climate for Cape Cod, Massachusetts. Quaternary Research 23:187-199. 